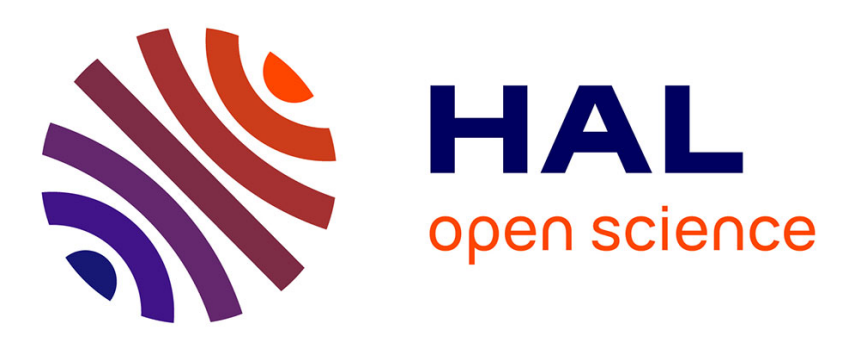

\title{
Guidelines for the restoration of the tropical timber tree Anacardium excelsum: first input from genetic data
}

Kelly Bocanegra-González, Marie-Laure Guillemin

\section{To cite this version:}

Kelly Bocanegra-González, Marie-Laure Guillemin. Guidelines for the restoration of the tropical timber tree Anacardium excelsum: first input from genetic data. Tree Genetics and Genomes, 2018, 14 (4), pp.14:59. 10.1007/s11295-018-1271-z . hal-02147361

\section{HAL Id: hal-02147361 https://hal.sorbonne-universite.fr/hal-02147361}

Submitted on 4 Jun 2019

HAL is a multi-disciplinary open access archive for the deposit and dissemination of scientific research documents, whether they are published or not. The documents may come from teaching and research institutions in France or abroad, or from public or private research centers.
L'archive ouverte pluridisciplinaire HAL, est destinée au dépôt et à la diffusion de documents scientifiques de niveau recherche, publiés ou non, émanant des établissements d'enseignement et de recherche français ou étrangers, des laboratoires publics ou privés. 


\section{Tree Genetics \& Genomes}

\section{Guidelines for the restoration of the tropical timber tree Anacardium excelsum: first input from genetic data \\ --Manuscript Draft--}

\begin{tabular}{|c|c|c|}
\hline Manuscript Number: & \multicolumn{2}{|l|}{ TGGE-D-17-00267R2 } \\
\hline Full Title: & \multicolumn{2}{|c|}{$\begin{array}{l}\text { Guidelines for the restoration of the tropical timber tree Anacardium excelsum: first } \\
\text { input from genetic data }\end{array}$} \\
\hline Article Type: & \multicolumn{2}{|l|}{ Original Article } \\
\hline Funding Information: & $\begin{array}{l}\text { Universidad del Tolima } \\
(043-16)\end{array}$ & Mrs Kelly Tatiana Bocanegra González \\
\hline Abstract: & \multicolumn{2}{|c|}{$\begin{array}{l}\text { Translocation of trees has been used as a common method to mediate genetic } \\
\text { conservation and restoration of forests. However, very few programs include strategies } \\
\text { developed to recover or maintain the genetic diversity of the translocated species. } \\
\text { Anacardium excelsum is a tree native to the tropics of America that is extensively used } \\
\text { in forestry. In Colombia, restoration of forests through the translocation of native } \\
\text { species has regained importance, and A. excelsum has been recently included in the } \\
\text { National Strategy for Plant Conservation. Thus, in order to define the level of genetic } \\
\text { structure and the level of genetic diversity within certain regions where remnants of the } \\
\text { seasonally dry tropical forests (SDTF) of Colombia have been retained, we genotyped } \\
106 \text { trees using nuclear Inter-Simple Sequence Repeats (ISSR) and sequenced two } \\
\text { non-coding chloroplast loci for these specimens. Our ISSR dataset revealed, the } \\
\text { existence of a gradient in genetic diversity within A. excelsum with the most diverse } \\
\text { remnants encountered in the south of the country, while the localities sampled in the } \\
\text { Caribbean coast and in the Chicamocha canyon were less diverse. Chloroplast loci } \\
\text { also pointed out the very low genetic diversity of A. excelsum from the Chicamocha } \\
\text { canyon and we propose to prioritize this area within future conservation programs. } \\
\text { Both chloroplast and nuclear markers supported the existence of genetic divergence } \\
\text { between distinct regions of Colombia, uncovering genetic differences between inter- } \\
\text { Andean, Caribbean and Chicamocha canyon A. excelsum remnants. Hence, we advise } \\
\text { to choose the provenance of seeds or plants carefully before translocation, and to } \\
\text { consider minimal mixing of material from different regions when initializing restoration } \\
\text { programs for A. excelsum, in Colombia. }\end{array}$} \\
\hline Corresponding Author: & $\begin{array}{l}\text { Kelly T. Bocanegra-Gon } \\
\text { Universidad del Tolima } \\
\text { Ibagué, Tolima COLOM }\end{array}$ & \\
\hline \multicolumn{3}{|l|}{$\begin{array}{l}\text { Corresponding Author Secondary } \\
\text { Information: }\end{array}$} \\
\hline Corresponding Author's Institution: & \multicolumn{2}{|l|}{ Universidad del Tolima } \\
\hline \multicolumn{3}{|l|}{$\begin{array}{l}\text { Corresponding Author's Secondary } \\
\text { Institution: }\end{array}$} \\
\hline First Author: & \multicolumn{2}{|c|}{ Kelly Tatiana Bocanegra González, M.Sc } \\
\hline \multicolumn{3}{|l|}{ First Author Secondary Information: } \\
\hline \multirow[t]{2}{*}{ Order of Authors: } & \multicolumn{2}{|c|}{ Kelly Tatiana Bocanegra González, M.Sc } \\
\hline & \multicolumn{2}{|c|}{ Marie-Laure Guillemin, Ph.D } \\
\hline \multicolumn{3}{|c|}{ Order of Authors Secondary Information: } \\
\hline Author Comments: & & \\
\hline
\end{tabular}


1

2 Guidelines for the restoration of the tropical timber tree Anacardium excelsum: first input from genetic data 3

4 Kelly T. Bocanegra-González ${ }^{1}$ \& Marie-Laure Guillemin ${ }^{2,3}$

5

6 맘opo de Investigación en Biodiversidad y Dinámica de Ecosistemas Tropicales, Facultad de Ingeniería

7 Forestal, Universidad del Tolima. Ibagué 730001, Colombia.

8 ktbocanegrag@gmail.com

$9 \quad+525568663854$

10 2Instituto de Ciencias Ambientales y Evolutivas, Facultad de Ciencias, Universidad Austral de Chile, Casilla 11567 , Valdivia 5090000, Chile.

$12{ }^{3}$ CNRS, Sorbonne Universités, UPMC University Paris VI, UMI 3614, Evolutionary Biology and Ecology of 13 Algae, Station Biologique de Roscoff, CS 90074, Place G. Teissier, 29680 Roscoff, France.

14 marielaure.guillemin@gmail.com

15

16 KT Bocanegra-González and M-L Guillemin contributed equally to this manuscript

17 Corresponding author: ktbocanegrag@gmail.com

18

19

20

21

22

23

24

25

26

27 
29 Abstract

30 Translocation of trees has been used as a common method to mediate genetic conservation and restoration of

31 forests. However, very few programs include strategies developed to recover or maintain the genetic diversity

32 of the translocated species. Anacardium excelsum is a tree native to the tropics of America that is extensively

33 used in forestry. In Colombia, restoration of forests through the translocation of native species has regained

34 importance, and A. excelsum has been recently included in the National Strategy for Plant Conservation. Thus,

35 in order to define the level of genetic structure and the level of genetic diversity within certain regions where

36 remnants of the seasonally dry tropical forests (SDTF) of Colombia have been retained, we genotyped 106

37 trees using nuclear Inter-Simple Sequence Repeats (ISSR) and sequenced two non-coding chloroplast loci for

38 these specimens. Our ISSR dataset revealed, the existence of a gradient in genetic diversity within $A$.

39 excelsum with the most diverse remnants encountered in the south of the country, while the localities sampled

40 in the Caribbean coast and in the Chicamocha canyon were less diverse. Chloroplast loci also pointed out the

41 very low genetic diversity of A. excelsum from the Chicamocha canyon and we propose to prioritize this area

42 within future conservation programs. Both chloroplast and nuclear markers supported the existence of genetic

43 divergence between distinct regions of Colombia, uncovering genetic differences between inter-Andean,

44 Caribbean and Chicamocha canyon A. excelsum remnants. Hence, we advise to choose the provenance of

45 seeds or plants carefully before translocation, and to consider minimal mixing of material from different

46 regions when initializing restoration programs for A. excelsum, in Colombia.

48 Key words: National Strategy for Plant Conservation of Colombia, translocations, seasonally dry tropical

49 forest, molecular markers, ISSR, cpDNA

50

51 Introduction

52 During the last decades, increased efforts to restore habitats degraded by human activities throughout the

53 world have been made (Meli et al. 2017). In the case of tropical forests, most of these efforts have focused on

54 restoring species diversity and forest structure post-logging, while only a limited number have focused on

55 controlling the erosion of genetic diversity or help restore this diversity among species of ecological and 
economical importance (Ang et al. 2017). It is clear that, from a holistic point of view, the focus of ecological

57 restoration should consider different levels of organization from genes to ecosystems (Hughes et al. 2008;

58 Aerts and Honnay 2011) and that ecosystem restoration should begin with or at least include a strategy

59 developed to recover or maintain genetic diversity of key stone species (Lesica and Allendorf 1999).

60 According to McKay (2005), a better understanding of how genetic variation is distributed within and among

61 populations (connected by varying degrees of gene flow) is essential for professionals in charge of restoration

62 programs to maintain historic gene flow and local adaptation. Such reforestation programs that take into

63 account the existence of regional genetic differentiation and possible local adaptations are, then, more likely

64 granted to restore ecosystem services in the long term (Menges 2008).

65 Knowledge about the distribution of genetic variation is key when strategical decisions have to be taken in

66 reforestation programs and should be used to assess, for example, the provenance of seeds or plants and the

67 degree to which material of different populations is mixed before restoration (Hughes et al. 2008; Aerts and

68 Honnay 2011). To mediate genetic conservation and restoration, the practice commonly referred as

69 "translocation" is frequently used. Translocation consists in the transport of individuals, usually from

70 healthier and bigger populations, to other areas of the species' distribution where populations are extinct or

71 struggling. Translocation has been key in establishing new populations or re-establishing extirpated

72 populations and to increase numbers of individuals in critically small populations (Menges 2008; Weeks et al.

73 2011). On the one hand, as in the case of the palm tree Pseudophoenix sargentii in Florida (Maschinski and

74 Duquesnel 2007), this technique has proven to be a very successful mean to counteract genetic erosion,

75 allowing to preserve the evolutionary potential of this endangered species. On the other hand, the

76 unsuccessful restoration experiments through translocations of seeds from Pinus pinaster in Western Europe

77 highlight the importance of acquisition of previous knowledge about the genetic structure of the species of

78 interest (Benito-Garzón et al. 2013). Indeed, transplanted populations of $P$. pinaster have been unable to settle

79 in sites characterized by climatic conditions different from the ones encountered in the seedlings' area of

80 origin; a result that has been related to the existence of local adaptation across the species' natural range

81 (Benito-Garzón et al. 2013). Unfortunately, it seems that the case of $P$. pinaster is not unique and that more

82 negative than positive experiences are reported in the process of restoration through translocations (Keller et

83 al. 2000; Menges et al. 2016). It is possible that a failure at integrating knowledge not only on the species 
84 taxonomy, reproductive biology, demography, and ecology but also on the distribution of genetic diversity

85 and functional adaptive traits between populations before choosing "whom to translocate where", account for

86 the majority of unsuccessful restoration programs (Lesica and Allendorf 1999; Menges 2008; Aerts and

87 Honnay 2011).

88 Moreover, restoring ecosystem functions and biological diversity often requires the use of species specific to 89 that habitat (Lesica and Allendorf 1999; McKay 2005; Benito-Garzón et al. 2013), and the need to use native 90 species in ecological restoration processes has been much emphasized lately. Although most processes of 91 reclamation of degraded land have been accomplished using exotic species (Lamb 1998; D’Antonio \& 92 Meyerson 2002), in recent years, projects that include species native to the ecosystems to be recovered have 93 increased. For example, in Colombia, there have been recent initiatives to restore the seasonally dry tropical 94 forests (SDTF) using native species (Thomas et al. 2017; Galindo-Rodríguez and Roa-Fuentes 2017).

95 Anacardium excelsum is a native tree of the tropics of America, and can be found in riparian forests of the dry 96 tropical and premontane areas from Guatemala to the northern part of South America, including the Guianas 97 (Bernal et al. 2015). This species is used extensively in forestry and, although it has been described as having 98 medium to slow growth rates, a recent study showed that it can reach the desired dimensions and 99 characteristics for logging in approximately 20 years (Lozano et al. 2012). This feature, together with its 100 capacity to grow in a wide range of soils and climatic conditions, makes A. excelsum an ideal native candidate 101 for ecological restoration programs of riparian and lowland forests of Central and South America (Lamb 102 1998; Garen et al. 2011). In spite of these interesting features, habitat loss and overexploitation are now 103 threatening A. excelsum populations, especially in Panamá and Colombia (Condit et al. 1995; Cárdenas and 104 Salinas 2007). Recent interest in the restoration of A. excelsum populations through translocation has emerged, 105 and the species has been included in the National Strategy for Plant Conservation of Colombia (NSPC) 106 (Pizano and García 2014). Indeed, A. excelsum is part of the red list of threatened Colombian timber trees 107 (Cárdenas and Salinas 2007) and is moreover characteristic to the SDTF, a habitat prioritized in the NSPC 108 (Pizano and García 2014). The high fragmentation of SDTFs and the isolation of A. excelsum populations 109 located in these remnants suggest that genetic differentiation could exist within the country. However, no 110 information about the genetic structure and diversity of A. excelsum is currently available, and no specific 111 molecular tools have been developed to work on these trees. 
112 In the American tropics, floristic differences (Banda-R et al. 2016) and the genetic structure of species of trees

113 commonly encountered in SDTF remnants (Caetano et al. 2008; Thomas et al. 2017) have been shown to be

114 determined by historical (i.e. Pleistocene and Holocene) as well as more current changes affecting the

115 ecosystem. Indeed, the Pleistocene Arc theory proposes that species characteristic to SDTF ecosystems had

116 largely contiguous distributions during the late Pleistocene's cool and dry glacial period, and that contractions

117 in present-day SDTF remnants correspond to a more recent change due to climate warming during the

118 Holocene (Prado and Gibbs 1993; Pennington et al. 2000). Anacardium excelsum populations could thus have

119 been much larger and highly connected in the past. Moreover, from the 1500's onwards, anthropogenic

120 disturbance linked to human settlement after European colonization have severely degraded SDTF remnants

121 (Valencia-Duarte et al. 2012; Pizano and García 2014). This could have led to further restriction in gene flow

122 and loss of genetic diversity through bottlenecks in A. excelsum.

123 In order to define the level of genetic structure between regions, and the level of genetic diversity within

124 regions and within remnants of A. excelsum in Colombia, we genotyped 106 trees collected from the

125 department of Bolívar in the north, down to the department of the Valle del Cauca in the south using nuclear

126 Inter-Simple Sequence Repeats (ISSRs), and also sequenced two non-coding chloroplast (cpDNA) loci. ISSR

127 and cpDNA loci represent molecular markers with highly distinct evolutionary rates. ISSRs are highly

128 polymorphic since their primers anneal directly on the SSR repeats distributed in the genome, which exhibit a

129 high rate of mutation classically linked to additions and losses of repeat units due to DNA slippage (Tuisima

130 et al. 2016). Conversely, the low rate of nucleotide substitutions, characteristic to the chloroplast genome in

131 plants, has been used to develop molecular markers well suited for phylogenetic and phylogeographic studies

132 (Hamilton 1999). Thus, we hypothesize that cpDNA loci will provide information about ancient gene flow (as

133 their sequences are rather conserved over time), while our ISSR results will reflect more recent patterns of

134 connectivity between A. excelsum remnants in Colombia. We further investigate population genetic footprints

135 of past climatic changes and current anthropogenic disturbances in a tree species characteristic to the

136 Colombian SDTFs. Ultimately, the aim of our study is to directly contribute to an effective and sustainable

137 restoration of A. excelsum by providing the first genetic information available for this native species in

\section{Colombia.}

139 
Materials and methods

141 1. Field sampling

142 Young and healthy leaves of 106 reproductive individuals of Anacardium excelsum were sampled between

143 September 2016 and March 2017, at 13 sites located in different fragments of Colombia's SDTF (see Table 1

144 and Results section for more details on region of origin and position of the sampling sites). Individuals

145 separated by distances of at least 50 meters were sampled in order to reduce the sampling of genetically

146 closely related individuals. A. excelsum is generally characterized by an outcrossing breeding system but the

147 species also partially displays flower that are self-compatible (Ghazoul and McLeish 2001). Flowers are

148 mainly pollinated by small bees (i.e. Trigona bees) and seed dispersal is mediated by bats. Sampling localities

149 were selected based on occurrence data of A. excelsum obtained from botanical collection records. The

150 locality of BOL, situated in the Caribbean coast (Table 1), was sampled from a botanical garden. Even if the

151 botanical garden Guillermos Piñeres (BOL) includes a four-hectare patch of SDTF forest, which has been

152 mostly dedicated to the study and protection of plants native to the Caribbean region of Colombia, no

153 information about the origin of its A. excelsum trees is available (e.g., the possibility of seedlings or

154 transplants originating from other regions). All dried tissue samples were stored in silica gel for posterior

155 DNA extraction.

156

157 2. DNA extraction, PCR amplification and sequencing

158 Total genomic DNA was extracted using the protocol described by Doyle (1987).

159 Ten ISSRs primers were used for genotyping (Table S1). Amplification cycles consisted of a 5 minutes

160 initiation step at $94^{\circ} \mathrm{C}$, followed by 40 amplification cycles consisting of a denaturation step at $94^{\circ} \mathrm{C}$ for 1

161 minute, annealing at $46^{\circ} \mathrm{C}-57^{\circ} \mathrm{C}$ for 45 seconds (Table S1) and a $72^{\circ} \mathrm{C}$ extension step for 2 minutes. Each

162 PCR was set up in a volume of $20 \mu 1$ using a PCR mix of: $3 \mu 1$ of DNA (corresponding to more or less 10ng);

$1632 \mu \mathrm{l}$ of PCR 10X buffer; $2 \mu \mathrm{l}$ of $2.5 \mathrm{mM}$ dNTP; $1.8 \mu \mathrm{l}$ of $25 \mathrm{mM} \mathrm{MgCl}_{2} ; 0.9 \mu \mathrm{l}$ of $2.5 \mathrm{mg} / \mathrm{mL} \mathrm{BSA} ; 0.4 \mu \mathrm{l}$ of $5 \mathrm{U} / \mu \mathrm{l}$

164 Taq DNA polymerase (Invitrogen, Carlsbad, USA), $0.8 \mu$ l of $2 \mu \mathrm{M}$ primer, and the remaining volume being

165 completed by pure water. The amplification products were visualized on a $2 \%$ agarose gel (w/v) including $2 \mu \mathrm{l}$

166 of GelRed ${ }^{\mathrm{TM}}$ (Biotium, Fremont, USA) and separated by horizontal electrophoresis for 1h20. To ensure

167 consistent scoring of the bands, all 106 individuals were scored on the same gel for each ISSR. 
168 GeneRuler 100 bp (Thermo Scientific, Massachusetts, USA) was used as molecular weight marker. After

169 electrophoresis, agarose gels were photographed by Gel Doc NEQ-11 (Neon Creative Labware, Santiago,

170 Chile) under ultraviolet light.

171 Two chloroplast intergenic spacers, $\operatorname{trn} \mathrm{L}-\operatorname{trn} \mathrm{F}$ (Taberlet et al. 1991) and rpl20-rps12 (Hamilton, 1999) were

172 sequenced. For $\operatorname{trn} \mathrm{L}-\operatorname{trn} \mathrm{F}$ we used the primers B49317 5'-CGAAATCGGTAGACGCTACG-3' and A50272

173 5'-ATTTGAACTGGTGACACGAG-3' described in Taberlet et al. (1991). For rpl20-rps 12, the primers

$174 r$ rpl20 5'-TTTGTTCTACGTCTCCGAGC-3' and rps12 5'-GTCGAGGAACATGTACTAGG-3' were used

175 (Hamilton 1999). Fragments were amplified by PCR in a $30 \mu 1$ volume using a mix similar to the one

176 described above for the ISSRs but with a final concentration of $0.2 \mathrm{mM} \mathrm{MgCl}_{2}, 0.4 \mathrm{mM}$ of each primer, and

$1770.2 \mathrm{mM}$ of each dNTP. A volume of $0.2 \mu \mathrm{l}$ of $5 \mathrm{U} / \mu 1$ Taq DNA polymerase (Invitrogen, Carlsbad, USA) was

178 used for each PCR. For both cpDNA loci, the amplification was done following the PCR cycling parameters

179 proposed by Taberlet et al. (1991). Products were purified using MoBio UltraClean ${ }^{\circledR}$ DNA (Solana Beach,

180 USA) and sequenced using both PCR primers, at Macrogen (https://dna.macrogen.com). The distinct

181 haplotypes detected were deposited in GENBANK under accession numbers MG309720-MG309723 and

182 MG309724-MG309726 for rpl20-rps12 and trnL-trnF, respectively.

183

184 3. Statistical analysis

185 ISSR amplified fragments were scored manually as absent (0) or present (1) to build a binary matrix, and 186 amplification failure of a sample was treated as missing data (-1). All ISSRs were amplified and scored twice

187 in order to limit the number of missing data. Each band was assumed to represent the phenotype at a single

188 biallellic locus (Crema et al. 2009). Classical parameters of genetic diversity suitable for

189 dominant molecular markers, calculated using GenAlEx 6.5 (Peakall \& Smouse 2012), were: average number

190 of effective alleles (Ne), number of private bands (Pa), Shannon index (I), and expected heterozygosity (He).

191 GenAlEx 6.5 was further used to calculate Nei's genetic distance (Nei 1978) in order to conduct a Principal

192 Coordinates Analysis (PCoA), and to construct a dendrogram using Sequential Agglomerative, Hierarchical,

193 and Nested Clustering (SAHN, in NTSYS-pc; Rohlf 1992). A population genetic structure analysis was

194 carried out based on the model of Bayesian grouping implemented in STRUCTURE (Pritchard et al. 2000).

195 The LOCPRIOR option was implemented to detect weak signals of population structure (i.e. includes a priori 
sampling locations as prior information in the clustering algorithm; Hubisz et al. 2009). The admixture model

197 was run, assuming correlated allele frequencies (Falush et al. 2003), using an initial burn-in of 500,000

198 followed by 1,000,000 Markov chain Monte Carlo (MCMC) iterations. Seven independent runs were

199 performed with the tested number of clusters (K) varying from 1 to 13 (i.e., the number of sites with ISSR

200 data +1$)$. Values obtained for the mean posterior probability of the data $(\operatorname{Ln} \operatorname{Pr}(X \mid K))$ and calculated for each

201 value of K (Janes et al. 2017) were plotted in STRUCTURE HARVESTER

202 (http://taylor0.biology.ucla.edu/structureHarvester/). The clear maximum of the $\operatorname{Ln} \operatorname{Pr}(\mathrm{X} \mid \mathrm{K})$ values was used

203 to define the optimal K. CLUMPP (Jakobsson and Rosenberg, 2007) was used to combine the results of the

204 seven independent runs, applying the greedy algorithm with 100,000 random input orders. To estimate the

205 partitioning of genetic variability among regions and among individuals within regions (Excoffier et al. 1992),

206 an analysis of molecular variance (AMOVA) was performed with GenAlEx 6.5 by resampling 9,999 times.

207 Pairwise values of $\Phi_{\mathrm{ST}}$ among regions were calculated with GenAlEx 6.5 and their significance was tested

208 using 9,999 permutations. For both the AMOVA and $\Phi_{\text {ST }}$ calculations, regions were defined as in Table 1 (i.e.

209 Magdalena river valley, Cauca river valley, Caribbean coast and Chicamocha canyon) and all individuals

210 from distinct sampling sites within each region were pooled. A Mantel test was performed with GENETIX

2114.05 (Belkhir et al. 1996-2004) to examine the relationship between Nei’s genetic distance and geographic

212 distance (estimated as ln of the geographical distance; Rousset 1997), and its significance was tested using

21310,000 permutations. ISSR data from BOL (i.e., the botanical garden) were not included when performing the

214 AMOVA among regions, the calculation of $\Phi_{\mathrm{ST}}$ among regions, and the test for isolation by distance.

215 Chloroplast sequences were edited in CHROMAS (Conor McCarthy, Griffith University, Australia,

216 http://www.technelysium.com.au/chromas.html) and aligned in MEGA7 (Kumar et al. 2016). The number of

217 haplotypes (nH), the number of polymorphic sites (S), gene diversity (Hd, Nei 1978) and nucleotide diversity

218 ( $\pi$, Nei and Li 1979) were computed using DnaSP (Rozas et al. 2003). Haplotypic richness (Re) was

219 estimated for each region using CONTRIB and the rarefaction procedure of Petit et al. (1998). Haplotypic

220 richness estimates reduce the effect of variation in sample size of A. excelsum among regions, with rarefaction

221 standardizing it to the smallest sample size. A rarefaction size of $\mathrm{N}=6$ was used, which corresponded to the

222 number of samples of the region with the lowest number of cpDNA sequences obtained (the Chicamocha

223 canyon; Table 1). For both chloroplast loci, a median-joining network was constructed using NETWORK v 
2244.5 (Bandelt et al. 1999). A rooted UPGMA tree was constructed in MEGA7 (Kumar et al. 2016) using the

225 concatenated trnL-trnF and rpl20-rps 12 sequences with 1,000 bootstrap replicates. Only one of each distinct

226 sequences was used and gaps were coded by hand as a $5^{\text {th }}$ character. Anacardium occidentale (Genbank

227 accession number: KY635877) was used as an outgroup. To estimate the partitioning of genetic variability

228 among regions and among individuals within region (Excoffier et al. 1992), analyses of molecular variance

229 (AMOVA) were performed with ARLEQUIN v. 3.5 (Excoffier et al. 2005) by resampling 10,000 times.

230 Pairwise values of $\Phi_{\mathrm{ST}}$ among regions were calculated with ARLEQUIN v. 3.5 and their significance was

231 tested using 10,000 permutations. For both, the AMOVA and $\Phi_{\mathrm{ST}}$ calculations, regions were defined as in

232 Table 1 and sequences from BOL were not included. As for ISSRs, all individuals from distinct sampling sites

233 within each region were pooled.

235 Results

236 Of the ten ISSR primers used for genotyping, three showed a high level of missing data (>5\%) and were

237 removed before analyses. Three individuals of the SUC population (Caribbean coast region; Table 1) also

238 showed a high level of missing data (i.e. more than half the ISSR primers did not amplify), and these

239 individuals were removed before analyses. For six individuals showing extremely poor DNA quality, no PCR

240 amplifications were possible. Thus, our ISSR analyses were performed on a total of 97 individuals, using

241 seven primers. Additionally, 89 sequences of trnL-trnF of 725-729bp and 92 sequences of rpl20-rps 12 of

$242 \quad 769$ bp were obtained.

243

244 1. Genetic diversity

245 The seven ISSR primers selected generated 57 fragments. Total number of fragments scored per primer

246 ranged from 6 to 10 (Table S1) with an average of $69.9 \%$ polymorphic loci within locality (Table 1). Shannon

247 index (I) and Nei's gene diversity (He) values ranged between 0.23-0.52 and 0.16-0.35, respectively, and the

248 two estimators showed the same pattern within Colombia. The highest values of I and He were observed in

249 the localities of the Magdalena river valley (i.e. ARM, MAR, IBG, VEN and CHA; Table 1). I and He

250 decreased then from the Magdalena river valley to the Cauca river valley, to the Caribbean coast and, at last,

251 to the Chicamocha canyon (Table 1$)$. The lowest values were encountered in $\mathrm{SAN}(\mathrm{I}=0.23, \mathrm{He}=0.16$; Table 
252 1). Among the ISSR markers, only one private fragment was observed for the primer UBC-809 (Table S1) in

253 VEN. When estimated by region, He was 0.35 in the Magdalena river valley, 0.32 in the Cauca river valley,

2540.25 in the Caribbean coast and 0.18 in the Chicamocha canyon.

255 Three haplotypes were observed for $\operatorname{trn} \mathrm{L}-\operatorname{trn} \mathrm{F}$ with five polymorphic sites that included a gap of $4 \mathrm{bp}$ (Table

256 2). For rpl20-rps 12, four haplotypes and three polymorphic sites were encountered (Table 2). Haplotypic

257 diversity within locality was generally very low and only one haplotype was observed for both loci in most

258 localities (i.e. ARM, IBG, CHA, CLI, QUI and SAN; Table 2). The highest values of diversity were observed 259 in the Caribbean coast (BOL: $\mathrm{Hd}=1.00$ and $0.67, \pi=4.5710^{-3}$ and $2.6010^{-3}$ for $\operatorname{trn} \mathrm{L}-\mathrm{trnF}$ and $r p l 20-r p s 12$, 260 respectively; CES: $\mathrm{Hd}=1.00, \pi=2.6010^{-3}$ for rpl20-rps 12; Table 2). Intermediate values were observed in 261 MED and MAR for both loci and in VEN for rpl20-rps12 (Table 2). When estimated by region, haplotypic 262 richness $(\mathrm{Re})$ was 2.0 and 2.0 in the Caribbean coast, 0.9 and 0.8 in the Cauca river valley, 0.1 and 0.4 in the 263 Magdalena river valley, and 0.0 and 0.0 in Chicamocha canyon (values given for $t r n \mathrm{~L}-t r n \mathrm{~F}$ and $r p l 20-r p s 12$, 264 respectively).

2. Genetic structure

267 The first two axes of the PCoA explained $42.97 \%$ and $23.62 \%$ of the genetic variability observed with the 268 ISSR data set for A. excelsum in Colombia (Fig.1). All localities from the Magdalena and Cauca river valleys 269 and the botanical garden sampled within the region of the Caribbean coast (BOL), clustered together. COR 270 and CES (Caribbean coast), and SAN (Chicamocha canyon) were isolated from the cluster of Magdalena, 271 Cauca and BOL (i.e. along axis 1 for the first two localities and along axis 2 for SAN). The closest localities 272 to SAN in the PCoA were CES and MED. The dendrogram based on Nei's genetic distance grouped the 273 localities from the south/center of the country (ARM, MAR, IBG, VEN, CLI, QUI, CHA) and BOL (Fig. 2C). 274 High genetic distances were observed between this group and COR and CES from the Caribbean coast, SAN 275 from the Chicamocha canyon and MED located at the far north of the Cauca river valley (Fig. 2). Of all these 276 four last localities, only SAN and MED clustered together. The Bayesian analysis carried out in

277 STRUCTURE for all localities shows the existence of three predominant genetic clusters (Fig. 3A). Most 278 individuals displayed varying degrees of mixed ancestry, and two of the three clusters present a rather 279 restricted geographic distribution (Fig. 3B and C). Individuals assigned, with a membership of 0.60 or higher, 
280 to the red genetic cluster were only observed in the Magdalena river valley (Fig. 3C) while individuals

281 assigned to the yellow genetic cluster were observed in the Magdalena river valley, the northern part of the

282 Cauca river valley and Chicamocha canyon (Fig. 3C). Interestingly, all trees sampled in SAN were assigned

283 to the yellow genetic cluster and presented a very low level of admixture (Fig. 3B). Individuals assigned to

284 the blue genetic cluster with a membership of 0.60 or higher were observed in all the sampled localities

285 excepting SAN (Fig. 3C). Geographic isolation strongly influenced genetic differentiation among localities, as

286 demonstrated by the significant correlation observed between genetic distance and $\ln$ of geographic distance

$287(\mathrm{r}=0.749, p<0.01)$ based on the Mantel test (Fig. S1). Significant genetic differences among regions were

288 detected by AMOVA, however, only $6 \%$ of the total of genetic variation was attributed to differences among

289 regions (Table 3). Significant genetic differentiation $\left(\Phi_{\mathrm{ST}}\right)$ was observed between all pairs of regions, except

290 between the Cauca river valley and the Caribbean coast (Table S2).

291 Due to the low level of haplotypic diversity, the structuration pattern observed with the two chloroplastic loci

292 was not clear-cut (Table 2, Fig. 2B). For trnL-trnF, haplotype H2 was observed in all regions and H1 in all

293 regions except in the Chicamocha canyon. Haplotype H3 was less frequent and encountered only in the

294 Caribbean coast. For rpl20-rps12, H1 was encountered in all regions except the Chicamocha canyon and H2

295 in all regions except in the Caribbean coast. Haplotypes H3 and H4 were less frequent and only observed in

296 the Magdalena river valley and the Caribbean coast. The UPGMA tree based on the concatenated sequences

297 of $\operatorname{trn} \mathrm{L}-\operatorname{trn} \mathrm{F}$ and $r p l 20-r p s 12$ revealed two branches supported by bootstrap values $>75 \%$ (Fig. 4 ). With the

298 exception of two individuals (one from BOL and one from MAR), the tree retrieved a geographical pattern

299 with the first group corresponding to the Caribbean coast and the Chicamocha canyon and the second group to

300 the Magdalena and the Cauca river valleys (Fig. 4). For both loci, AMOVAs attributed a majority of the

301 variance to partition among geographic regions ( $75 \%$ and 57\% for $\operatorname{trn} \mathrm{L}-\operatorname{trnF}$ and $r p l 20$-rps 12, respectively;

302 Table 3). As for ISSR data, significant genetic differentiation $\left(\Phi_{\mathrm{ST}}\right)$ was also observed between all pairs of

303 regions, except between the Cauca river valley and the Caribbean coast, for the two chloroplastic loci (Table

304 S2).

305

306 Discussion 
307 For ISSR markers, our study revealed the existence of a gradient of genetic diversity within Anacardium

308 excelsum in Colombia, with the most diverse remnants encountered in the south (i.e. the region of the

309 Magdalena river valley and of the Cauca river valley), while the localities sampled in the Caribbean coast and

310 in the Chicamocha canyon were less diverse. Except for the Chicamocha canyon where the lowest haplotypic

311 richness was also observed for both $\operatorname{trn} \mathrm{L}-\mathrm{trnF}$ and $r p l 20-r p s 12$, this pattern was not retrieved for the two

312 chloroplastic loci. Both chloroplast and nuclear markers supported the existence of genetic divergence

313 between distinct regions of Colombia. Caribbean coast exhibited unique haplotype diversity for $\operatorname{trnL}-\operatorname{trn} \mathrm{F}$

314 chloroplastic locus while two ISSR genetic clusters seem mostly restricted to the southeast of the country.

315 Some of our results pointed to the existence of a pattern of spatial genetic structure in A. excelsum. Indeed, the

316 dendrogram obtained using the ISSR data grouped most of the localities of the inter-Andean valleys (except

317 MED; Fig. 2). In the same way, the concatenated sequences of the two chloroplastic loci characterizing

318 samples from the Magdalena and the Cauca river valleys form a well-supported branch in the UPGMA tree

319 (Fig. 4). Moreover, PCoA based on the ISSR dataset isolated SAN (i.e. Chicamocha canyon) and CES and

320 COR (i.e. Caribbean coast) from the rest of the populations sampled (Fig. 1). Taken together, our results

321 uncovered a slight genetic divergence between inter-Andean, Caribbean and Chicamocha canyon A. excelsum

322 remnants. Interestingly, for the two chloroplastic loci and the ISSR data, significant genetic differentiation

323 was observed between all region pairs except between the Cauca river valley and the Caribbean coast. We

324 propose that the existence of a past and/or current corridor of dispersal between these two regions may

325 explain our results. Higher genetic differences among regions were detected by AMOVAs based on the two

326 choloroplastic loci than when calculated with the ISSR data. The different evolutionary dynamics (i.e.

327 differences in strength of the genetic drift and migration and mutation rates) of nuclear and chloroplastic loci

328 could explain these contrasting results. Indeed, chloroplast

329 DNA (cpDNA) is uniparentally inherited and haploid and effective population size of chloroplast loci is four

330 times lower than the one of nuclear loci. Difference in type of inheritance could also lead to contrasting

331 migration rates between loci since cpDNA is only dispersed via seeds while nuclear loci are transmitted and

332 dispersed by both pollen and seeds. Moreover, choloroplastic loci are characterized by a low rate of

333 nucleotide substitution (Hamilton 1999), while ISSR data present a high mutation rate (Tuisima et al. 2016).

334 Because of these differences among marker types, chloroplastic loci have been suggested to better reveal 
335 historical changes, especially the population's response to Pleistocene glacial climatic variations, than nuclear

336 loci (Ennos et al. 1999). Contrasting with values of $\Phi_{\text {ST }}$ between regions reaching up to 0.969 for the

337 choloroplastic loci, our ISSR data showed a high level of admixture between the three genetic groups detected 338 by Bayesian clustering (except in SAN, COR and CES; Fig. 3) and an increasing genetic differentiation 339 among populations with increasing geographic distance (i.e., a pattern of isolation by distance; Fig. S1). We

340 propose that these slight differences in patterns of genetic divergence detected by our two types of molecular 341 markers could be related, in part, to the complex scenario of a combination of historical isolation followed by 342 more substantial gene flow after secondary contact.

343 Historical separation between inter-Andean and Caribbean SDTF remnants has been previously supported by 344 the existence of floristic differences (Pizano and García 2014) and by a strong genetic structure within species 345 distributed in the Caribbean coast and the Cauca river valley (e.g. the tree Enterolobium cyclocarpum;

346 Thomas et al. 2017). The range and distribution of SDTF fragments, and concomitantly of the A. excelsum 347 populations, has been molded by the history of the region. Recent studies suggest that genetic isolation 348 between SDTF tree populations predate the late Pleistocene (Caetano et al., 2008; Thomas et al., 2017), with 349 genetic differentiation building up in SDTF remnants isolated during the Neogene (Burnham and Carranco 350 2004; Côrtes et al., 2015). Secondary contact between differentiated genetic groups could have occurred 351 during the Pleistocene, a period during which the SDTF range is proposed to have been much larger 352 (Pennington 2009). Indeed, the Pleistocene Arc theory suggests that the present-day SDTF patches represent 353 only relics of a much more contiguous formation extending all around the Amazon basin from the northeast of 354 Brazil to Paraguay, including the inter-Andean valleys of Bolivia, Peru, Ecuador and Colombia, up to the 355 Caribbean coast of Colombia and Venezuela (Prado and Gibbs 1993; Pennington et al. 2000). Even if the 356 Pleistocene Arc theory has been questioned (Werneck et al. 2011), SDTFs are still considered to have 357 occupied a much larger area in the past especially in the north of South America, the Andean region from 358 Bolivia to Peru and along a northern Amazonian block including areas of Colombia, Venezuela and the 359 Guiana highlands. In Colombia, the historically larger areas of SDTF were likely connecting our four regions 360 under study (Pennington 2009; Thomas et al. 2017). The maximum extension of the SDTFs is suggested to 361 concur with the last Glacial-Holocene transition (Werneck et al. 2011). Additionally, a recent palynological 362 and geochemical study of a site close to Mount Paramillo has estimated that vegetation change linked to 
wetter and cooler climate, and then a possible recess of the SDTFs, in the northern termination of the

364 Colombian Western Cordillera could be as recent as 4,000 yr before present (Munoz-Uribe 2012). In general,

365 patterns of isolation by distance equilibrate relatively quickly and rely mostly on recent demographic events

366 (Barton et al. 2013). However, for species with long generation times such as some woody trees (trees are

367 generally considered long-lived perennials with lengthy juvenile period; e.g. in Anacardiaceae in Hormaza

368 and Wünsch 2007 and Dinesh et al. 2011), it is possible that the fragmentation of SDTFs is, in our case, yet

369 too recent $(<4,000 \mathrm{yr})$ to detect its genetic footprint and explains why a pattern of isolation by distance can

370 still be retrieved in A. excelsum. Human activities during the last century, as for example the usage of tree

371 seedlings or transplantation from different localities (e.g. one tree from the botanical garden of BOL located

372 in the Caribbean coast had chloroplastic haplotypes typically encountered in the southern part of the country;

373 Fig. 4) or forestry activity could also have artificially increased gene flow between some isolated A. excelsum

374 remnants and led to a recent admixture between differentiated genetic groups.

375 For both kinds of markers (ISSRs and chloroplast sequences), the locality of SAN, within the Chicamocha

376 canyon, presented the lowest level of genetic diversity for A. excelsum when compared to the other remnants

377 of Colombian SDTFs. Our analyses also provide evidence for possible genetic divergence of SAN from the

378 rest of the Colombian SDTF remnants of A. excelsum. During the last decades, this area has been shown to

379 suffer from high and persistent anthropogenic disturbance (Valencia-Duarte et al. 2012), a phenomenon

380 classically related to the existence of recurrent bottlenecks and low genetic diversity in plants (Young et al.

381 1996). We propose that anthropogenic disturbance could have increased the geographic isolations of relics

382 present in the Chicamocha canyon and that this may have ultimately limited gene flow between the natural

383 population of SAN and the rest of the Colombian SDTF remnants. The fragmentation of SDTFs has also led

384 to genetic isolation and inbreeding depression in other tree species in Brazil, such as Tabebuia ochracea

385 (Moreira et al. 2009), T. roseoalba, Handroanthus chrysotrichus, H. impetiginosus and H. serratifolius

386 (Collevatti et al. 2014). Inbreeding depression in plants could lead to a decrease in fecundity, in the number of

387 viable seeds as well as lower survival or lower resistance to stress. Identifying populations potentially affected

388 by inbreeding can be essential for the development of long-term conservation strategies (Keller and Waller

389 2002). An effect of forest fragmentation on pollination success and seed production was documented in $A$.

390 excelsum remnants in Costa Rica, a result possibly related to inbreeding depression in this partially self- 
391 incompatible tree (Ghazoul and McLeish 2001). Unfortunately, the markers used in our study are dominant

392 (i.e. ISSRs) or haploid (i.e. chloroplastic loci) and do not allow to test for possible traces of inbreeding in $A$.

393 excelsum populations. Thus, to facilitate the establishment of strategies that could mitigate risks of local

394 extinction in small isolated remnants of A. excelsum, complementary studies focusing on co-dominant

395 molecular markers such as microsatellites or SNPs (Single Nucleotide Polymorphisms) will have to be

396 undertaken.

397 Our study is the first attempt to provide genetic information at the country level for A.excelsum, a native

398 species representing a good candidate for local and national restoration programs of SDTFs. A. excelsum is

399 generally propagated by seeds since other methods, such as in vitro propagation or cuttings, have been proven

400 remarkably difficult (Barreto et al. 2007). No specific biological knowledge is required to grow A. excelsum

401 from seeds since the percentage of germination without any further treatment lies around $50 \%$ or higher

402 (Barreto et al. 2007). Restoration of SDTF is included in the National Strategy for Plant Conservation of

403 Colombia (NSPC), a recent environmental legislation aiming at the rehabilitation, recovery and conservation

404 of disturbed areas in Colombia (Pizano and García 2014; MiniAmbiente 2015). Herein, Regional

405 Autonomous Corporations (hereafter noted RAC) are in charge of the restoration and reforestation programs,

406 and have begun with the implementation of such plans for A. excelsum, as for example the RAC of

407 Cundinamarca (CAR) and the RAC of Tolima (CORTOLIMA) in the Magdalena river valley, and the RAC of

408 the Cauca Valley (CVC) and the RAC of Quindió (CRQ) in the Cauca river valley (Morales 2016, KT

409 Bocanegra-González pers. obs.). To meet the goals proposed in the NSPC, A. excelsum seedlings from

410 various nurseries and from different bioclimatic life zones (as defined by the Holdridge life zones system;

411 Holdridge 1947) are generally mixed up when reestablishing SDTFs, without considering the potential

412 introduction of new genetic variants and genetic pollution in the newly restored region, or the usage of seeds

413 that are poorly adapted to the new local conditions (MiniAmbiente 2015). Seedlings from mixed origins could

414 generate highly genetically diverse A. excelsum populations and potentially increase short-term resilience of

415 the reforested patches (Jump et al. 2009). However, this artificial gene flow can contribute to long-term

416 population decline via outbreeding depression and genetic swamping (see Hufford \& Mazer 2003 for a

417 review). Because we do not yet know enough to predict which crossing scenarios have a risk for outbreeding

418 depression in A. excelsum, we advise against mixing seeds or plants from regions showing genetic divergence, 
419 or using trees from off-regional sources in transplantation programs using A. excelsum. Finally, because of the

420 apparent genetic isolation and very low genetic diversity of A. excelsum in the Chicamocha canyon in the

421 state of Santander, we propose to prioritize this area within future conservation programs.

423 Acknowledgments

424 We would like to thank Fernando Fernández Méndez, Omar Aurelio Melo, Luis C. Acosta Cadenas, German

425 Urueña Serrano, Carlos A. Morales Carranza, Jeferson D. Galvis Jiménez, Sonia C. Camargo Roa, Jhon J.

426 Borda Velasquez, Ivan D. Vergara Terreros, Vannesa A. Montoya Sánchez, and Raul Rico Molina for their

427 assistance in the field and for providing samples of Anacardium excelsum from Colombia. We would like to

428 thank two anonymous reviewers and TGGE associated editor for their insightful and constructive comments.

429 This research was supported by the program "Talento Humano" $\mathrm{N}^{\circ} 043-16$ from the Universidad del Tolima

430 attributed to K. T. B-G.

431

432 Data Archiving Statement

433 The distinct haplotypes detected were deposited in GENBANK under numbers MG309720-MG309723 and

434 MG309724- MG309726 for rpl20-rps12 and trnL-trnF, respectively. This information is also available in the 435 materials and methods' section.

436

437 References

438 Aerts R, Honnay O (2011) Forest restoration, biodiversity and ecosystem functioning. BMC Ecology 11:29

439 Ang CC, O’Brien MJ, Ng KKS et al (2016) Genetic diversity of two tropical tree species of the

440 Dipterocarpaceae following logging and restoration in Borneo: high genetic diversity in plots with

441 high species diversity. Plant Ecol Divers 9:459-469

442 Banda-R K, Delgado-Salinas A, Dexter KG et al (2016) Plant diversity patterns in neotropical dry forests and 443 their conservation implications. Science 353:1383-1387

444 Bandelt HJ, Forster P, Röhl A (1999) Median-joining networks for inferring intraspecific phylogenies. Mol $445 \quad$ Biol Evol 16:37-48 
446 Barreto D, Valero N, Muñoz A et al (2007) Efecto de microorganismos rizosféricos sobre germinación y

447 crecimiento temprano de Anacardium excelsum. Zonas Áridas 11:240-250

448 Barton N, Etheridge A, Kelleher J, Véber A (2013) Inference in two dimensions: allele frequencies versus 449 lengths of shared sequence blocks. Theor Popu Biol 87:105-119

450 Belkhir K, Borsa P, Chikhi L, Raufaste N, Bonhomme F (1996-2004) Genetix 4.02, Logiciel sous Windows 451 TM pour la génétique des populations. Laboratoire Génome, Populations, Interactions, CNRS UMR 452 5000, Université de Montpellier II, Montpellier

453 Benito-Garzón M, Ha-Duong M, Frascaria-Lacoste N et al (2013) Habitat restoration and climate change: 454 dealing with climate variability, incomplete data, and management decisions with tree translocations. $455 \quad$ Restoration Ecol 21:530-536

456 Bernal R, Gradstein SR, Celis M (Eds) (2015) Catálogo de plantas y líquenes de Colombia. Instituto de 457 Ciencias Naturales, Universidad Nacional de Colombia. Available from:

$458 \quad \mathrm{http}: / /$ catalogoplantasdecolombia.unal.edu.co

459 Caetano S, Prado D, Pennington RT et al (2008) The history of Seasonally Dry Tropical Forests in eastern

460 South America: inferences from the genetic structure of the tree Astronium urundeuva

$461 \quad$ (Anacardiaceae). Mol Ecol 17:3147-3159

462 Cárdenas LD, Salinas NR (2007) Libro rojo de plantas de Colombia. Vol 4. Especies maderables amenazadas, 463 primera parte. Instituto Amazónico de Investigaciones Científicas (SINCHI), Bogotá, D.C.

464 Collevatti RG, Estolano R, Ribeiro ML et al (2014) High genetic diversity and contrasting fine-scale spatial 465 genetic structure in four seasonally dry tropical forest tree species. Plant Syst Evol 300:1671-1681

466 Condit R, Hubbell SP, Foster RB (1995) Demography and harvest potential of Latin American timber species: 467 data from a large, permanent plot in Panama. J Trop For Sci 7:599-622

468 Crema S, Cristofolini G, Rossi M et al (2009) High genetic diversity detected in the endemic Primula 469 apennina Widmer (Primulaceae) using ISSR fingerprinting. Plant Syst Evol 280:29-36

470 D'antonio C, Meyerson LA (2002) Exotic plant species as problems and solutions in ecological restoration: a $471 \quad$ synthesis. Restoration Ecol 10:703-713

472 Dinesh MR, Hemanth KV, Ravishankar KV et al (2011) Mangifera. In Kole C (Ed), Wild crop relatives: 473 genomic and breeding resources. Springer, Berlin, Heidelberg 
474 Doyle JJ (1987) A rapid DNA isolation procedure for small quantities of fresh leaf tissue. Phytochem Bull 19: $475 \quad 11-15$

476 Ennos RA (1999) Using organelle markers to elucidate the history, ecology and evolution of plant populations.

477 In: Hollingsworth PM, Bateman RM, Gornall RJ (eds) Molecular systematics and plant evolution, $478 \quad$ London and New York, pp 1-19

479 Excoffier L, Smouse PE, Quattro JM (1992) Analysis of molecular variance inferred from metric distances 480 among DNA haplotypes: application to human mitochondrial DNA restriction sites. Genetics $481 \quad 131: 479-491$

482 Excoffier L, Laval G, Schneider S (2005) Arlequin ver. 3.0: an integrated software package for population 483 genetics data analysis. Evol Bioinf Online 1:47-50

484 Falush D, Stephens M, Pritchard JK (2003) Inference of population structure using multilocus genotype data: 485 linked loci and correlated allele frequencies. Genetics 164:1567-1587

486 Galindo-Rodríguez C, Roa-Fuentes LL (2017) Seed desiccation tolerance and dispersal in tropical dry forests 487 in Colombia: Implications for ecological restoration. Forest Ecol Manag 404:289-293

488 Garen EJ, Saltonstall K, Ashton MS et al (2011) The tree planting and protecting culture of cattle ranchers 489 and small-scale agriculturalists in rural Panama: opportunities for reforestation and land restoration. $490 \quad$ Forest Ecol Manag 261:1684-1695

491 Ghazoul J, McLeish M (2001) Reproductive ecology of tropical forest trees in logged and fragmented habitats 492 in Thailand and Costa Rica. Plant Ecol 153:335-345

493 Holdridge LR (1947) Determination of world plant formations from simple climatic data. Science 105:367494

495 Hamilton MB (1999) Four primer pairs for the amplification of chloroplast intergenic regions with 496 intraspecific variation. Mol Ecol 8:521-523

497 Hormaza JI, Wünsch A (2007) Pistachio. In: Kole C (Ed), Genome mapping and molecular breeding in plants, 498 fruits and nuts, vol 4. Springer, Berlin, Heidelberg

499 Hubisz MJ, Falush D, Stephens M et al (2009). Inferring weak population structure with the assistance of 500 sample group information. Mol Ecol Resour 9:1322-1332 
501 Hufford KM, Mazer SJ (2003) Plant ecotypes: genetic differentiation in the age of ecological restoration.

$502 \quad$ Trends Plant Sci 18:147-155

503 Hughes AR, Inouye BD, Johnson MT (2008) Ecological consequences of genetic diversity. Ecol Lett 11:609$504 \quad 623$

505 Jakobsson M, Rosenberg NA (2007) CLUMPP: a cluster matching and permutation program for dealing with 506 label switching and multimodality in analysis of population structure. Bioinformatics 23:1801-1806

507 Janes KJ, Miller JM, Dupuis JR et al (2017) The K = 2 conundrum. Mol Ecol 26:3594-3602

508 Jump AS, Marchant R, Penuelas J (2009) Environmental change and the option value of genetic diversity. $509 \quad$ Trends Plant Sci 14:51-58

510 Keller M, Kollmann J, Edwards PJ (2000) Genetic introgression from distant provenances reduces fitness in $511 \quad$ local weed populations. J Appl Ecol 37:647-659

512 Keller LF, Waller DM (2002) Inbreeding effects in wild populations. Trends Ecol Evol 17:230-241

513 Kumar S, Stecher G, Tamura K (2016) MEGA7: Molecular Evolutionary Genetics Analysis version 7.0 for $514 \quad$ bigger datasets. Mol Biol Evol 33:1870-1874

515 Lamb D (1998) Large scale ecological restoration of degraded tropical forest lands: the potential role of 516 timber plantations. Restoration Ecol 6:271-279

517 Lesica P, Allendorf FW (1999) Ecological genetics and the restoration of plant communities: mix or match? $518 \quad$ Restoration Ecol 7:42-50

519 Lozano B, Franco O, Bonilla J (2012) Estimación del crecimiento diamétrico, de Anacardium excelsum

520 (Kunth) Skeels, por medio de modelos no lineales, en bosques naturales del departamento del Tolima.

$521 \quad$ Bol Cient Mus Hist Nat 16:19-32

522 McKay JK, Christian CE, Harrison S et al (2005) "How local is local?" - a review of practical and conceptual 523 issues in the genetics of restoration. Restoration Ecol 13:432-440

524 Maschinski J, Duquesnel J (2007) Successful reintroductions of the endangered long-lived Sargent's cherry 525 palm, Pseudophoenix sargentii, in the Florida Keys. Biol Cons 134:122-129

526 Meli P, Holl KD, Rey Benayas JM et al (2017) A global review of past land use, climate, and active vs. 527 passive restoration effects on forest recovery. Plos One 12:e0171368 
528 Menges ES (2008) Restoration demography and genetics of plants: when is a translocation successful? Aust J

529 Bot 56:187-196

530 Menges ES, Smith SA, Weekley CW (2016) Adaptive introductions: How multiple experiments and 531 comparisons to wild populations provide insights into requirements for long-term introduction 532 success of an endangered shrub. Plant Diversity 38:238-246

533 MiniAmbiente (2015) Plan Nacional de Restauración: restauración ecológica, rehabilitación y recuperación 534 de áreas disturbadas, Ministerio de Ambiente y Desarrollo Sostenible de Colombia, Bogotá D.C 535 (http://www.minambiente.gov.co/index.php/bosques-biodiversidad-y-servicios536 ecosistematicos/gestion-en-biodiversidad/restauracion-ecologica)

537 Morales GA (2016) Plan de manejo y conservación del Caracolí (Anacardium excelsum) en la jurisdicción $538 \quad$ CAR. Bogotá, Colombia.

539 Moreira PA, Fernandes GW, Collevatti RG (2009) Fragmentation and spatial genetic structure in Tabebuia $540 \quad$ ochracea (Bignoniaceae) a seasonally dry Neotropical tree. Forest Ecol Manag 258:2690-2695

541 Munoz-Uribe PA (2012) Holocene climate variability in tropical South America: case history from a high542 mountain wet zone in NW Colombia based on palynology and X-ray microfluorescence. PhD $543 \quad$ Dissertation, University of Geneva

544 Nei M (1978) Estimation of average heterozygosity and genetic distance from a small number of individuals. $545 \quad$ Genetics 89:583-590

546 Nei M, Li WH (1979) Mathematical model for studying genetic variation in terms of restriction 547 endonucleases. Proc Natl Acad Sci USA 76:5269-5273

548 Peakall R, Smouse PE (2012) GenAlEx 6.5: genetic analysis in Excel. Population genetic software for 549 teaching and research - an update. Bioinformatics 28:2537-2539

550 Pennington RT, Prado DE, Pendry CA (2000) Neotropical seasonally dry forests and Quaternary vegetation $551 \quad$ changes. J Biogeogr 27:261-273

552 Pennington RT, Lavin M, Oliveira-Filho A (2009) Woody plant diversity, evolution, and ecology in the 553 tropics: perspectives from seasonally dry tropical forests. Annu Rev Ecol Syst 40:437-457

554 Petit RJ, El Mousadik A, Pons O (1998) Identifying populations for conservation on the basis of genetic $555 \quad$ markers. Conserv Biol 12:844-855 
556 Pizano C, García H (Eds) (2014) El bosque seco tropical en Colombia. Instituto Alexander von Humbolt, $557 \quad$ Bogotá D.C

558 Prado DE, Gibbs PE (1993). Patterns of species distributions in the dry seasonal forests of South America. $559 \quad$ Ann Miss Bot Gard 80:902-927

560 Pritchard JK, Stephens M, Donnelly P (2000) Inference of population structure using multilocus genotype $561 \quad$ data. Genetics 155:945-959

562 Rohlf FJ (1992) NTSYS-pc: Numerical taxonomy and multivariate analysis system version 1.80. Exeter 563 Software. Department of Ecology and Evolution, State University of New York, New York.

564 Rousset F (1997) Genetic differentiation and estimation of gene flow from F-statistics under isolation by 565 distance. Genetics 145:1219-1228

566 Rozas J, Sánchez-DelBarrio JC, Messeguer X et al (2003) DnaSP, DNA polymorphism analyses by the $567 \quad$ coalescent and other methods. Bioinformatics 19:2496-2497

568 Taberlet P, Gielly L, Pautou G et al (1991) Universal primers for amplification of three non-coding regions of 569 chloroplast DNA. Plant Mol Biol 17:1105-1109

570 Thomas E, Tobón CG, Gutiérrez JP et al (2017). Genetic diversity of Enterolobium cyclocarpum in 571 Colombian seasonally dry tropical forest: implications for conservation and restoration. Biodivers $572 \quad$ Conserv 26:825-842

573 Tuisima LL, Hlásná-Čepková P, Lojka B, Weber JC, Alves-Milho SF (2016) Genetic diversity in Guazuma $574 \quad$ crinita from eleven provenances in the Peruvian Amazon revealed by ISSR markers. Bosque 37:63$575 \quad 70$

576 Valencia-Duarte J, Trujillo Ortiz LN, Vargas Ríos O (2012) Dinámica de la vegetación en un enclave 577 semiárido del río Chicamocha, Colombia. Biota Colomb13:40-59

578 Weeks AR, Sgro CM, Young AG et al (2011) Assessing the benefits and risks of translocations in changing 579 environments: a genetic perspective. Evol Appl 4:709-725

580 Werneck FP, Costa GC, Colli GR et al (2011). Revisiting the historical distribution of Seasonally Dry

581 Tropical Forests: new insights based on palaeodistribution modelling and palynological evidence. $582 \quad$ Global Ecol Biogeogr 20:272-288 
583 Young A, Boyle T, Brown T (1996) The population genetic consequences of habitat fragmentation for 584 plants. Trends Ecol Evol 11:413-418 
Table 1. Sampling localities of Anacardium excelsum and associated genetic diversity for seven inter-simple sequence repeat (ISSR) primers. For each locality,

$(\mathrm{Ne})$, percentage of polymorphic loci (\%P), Shannon's index (I), expected heterozygosity (He) are displayed.

\begin{tabular}{|c|c|c|c|c|c|c|c|c|}
\hline Region & Locality & Code & Geographic coordinates & $\mathrm{Ns} / \mathrm{Nsp}$ & $\mathrm{Ne}$ & $\% \mathrm{P}$ & $\mathrm{I}$ & $\mathrm{He}$ \\
\hline \multirow[t]{5}{*}{ Magdalena river valley } & Armero & ARM & $5^{\circ} 00^{\prime} 42.59^{\prime \prime} \mathrm{N} 74^{\circ} 54^{\prime} 39.35^{\prime \prime} \mathrm{W}$ & $15 / 14$ & 1.50 & 89.9 & 0.43 & 0.28 \\
\hline & Mariquita & MAR & $5^{\circ} 14^{\prime} 49.05^{\prime \prime} \mathrm{N} 74^{\circ} 53^{\prime} 20.60^{\prime \prime} \mathrm{W}$ & $15 / 13$ & 1.53 & 80.7 & 0.43 & 0.29 \\
\hline & Ibagué & IBG & $4^{\circ} 25^{\prime} 35.47^{\prime \prime} \mathrm{N} 75^{\circ} 12^{\prime} 46.66^{\prime \prime} \mathrm{W}$ & $16 / 16$ & 1.52 & 91.2 & 0.46 & 0.30 \\
\hline & Venadillo & VEN & $4^{\circ} 40^{\prime} 31.14^{\prime \prime} \mathrm{N} 74^{\circ} 49^{\prime} 20.06^{\prime \prime} \mathrm{W}$ & $15 / 15$ & 1.62 & 94.7 & 0.52 & 0.35 \\
\hline & Chaparral & $\mathrm{CHA}$ & $3^{\circ} 45^{\prime} 10.53^{\prime \prime} \mathrm{N} 75^{\circ} 32^{\prime} 26.29^{\prime \prime} \mathrm{W}$ & $6 / 4$ & 1.45 & 71.9 & 0.39 & 0.26 \\
\hline \multirow[t]{3}{*}{ Cauca river valley } & Medellín & MED & $6^{\circ} 19^{\prime} 35.09^{\prime \prime} \mathrm{N} 75^{\circ} 30^{\prime} 44.34^{\prime \prime} \mathrm{W}$ & $5 / 5$ & 1.36 & 56.1 & 0.31 & 0.20 \\
\hline & Cali & CLI & $3^{\circ} 26^{\prime} 52.31^{\prime \prime} \mathrm{N} 76^{\circ} 33^{\prime} 30.44^{\prime \prime} \mathrm{W}$ & $10 / 10$ & 1.50 & 85.9 & 0.45 & 0.30 \\
\hline & Armenia & QUI & $4^{\circ} 30^{\prime} 43.23^{\prime \prime} \mathrm{N} 75^{\circ} 39^{\prime} 03.07^{\prime \prime} \mathrm{W}$ & $5 / 5$ & 1.43 & 75.4 & 0.39 & 0.25 \\
\hline \multirow[t]{4}{*}{ Caribbean coast } & Pueblo nuevo & COR & 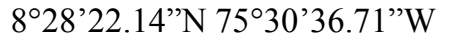 & $3 / 3$ & 1.42 & 57.8 & 0.34 & 0.23 \\
\hline & Turbaco & BOL & $10^{\circ} 33^{\prime} 44.54^{\prime \prime} \mathrm{N} 75^{\circ} 22^{\prime} 30.71^{\prime \prime} \mathrm{W}$ & $3 / 3$ & 1.39 & 59.6 & 0.33 & 0.22 \\
\hline & Manaure & CES & $10^{\circ} 13^{\prime} 56.89^{\prime \prime} \mathrm{N} 73^{\circ} 02^{\prime} 03.08^{\prime \prime} \mathrm{W}$ & $3 / 3$ & 1.30 & 40.3 & 0.24 & 0.16 \\
\hline & Corozal & SUC & $9^{\circ} 17^{\prime} 16.62^{\prime \prime} \mathrm{N} 75^{\circ} 13^{\prime} 44.68^{\prime \prime} \mathrm{W}$ & $4 / 0$ & - & - & - & - \\
\hline Chicamocha canyon & Bucaramanga & SAN & $7^{\circ} 07^{\prime} 14.40^{\prime \prime} \mathrm{N} 73^{\circ} 08^{\prime} 39.89^{\prime \prime} \mathrm{W}$ & $6 / 6$ & 1.30 & 40.3 & 0.23 & 0.16 \\
\hline Mean & & & & & & 69.9 & 0.38 & 0.23 \\
\hline
\end{tabular}


number of sequences $(\mathrm{N})$; number of haplotypes $(\mathrm{nH})$; gene diversity $(\mathrm{Hd})$; nucleotide diversity $(\pi)$; number of polymorphic sites $(\mathrm{S})$ and a list of haplotypes

(Hap) are given. In the haplotype list, the haplotype's name is directly followed by the number of sampled individuals carrying that haplotype, in parentheses.

\begin{tabular}{|c|c|c|c|c|c|c|c|c|c|c|c|c|c|}
\hline & & \multicolumn{6}{|c|}{$\operatorname{trn} \mathrm{L}-\operatorname{trn} \mathrm{F}$} & \multicolumn{6}{|c|}{ rpl20-rps12 } \\
\hline Region & Code & $\mathrm{N}$ & $\mathrm{nH}$ & $\mathrm{Hd}$ & $\pi\left(.10^{-3}\right)$ & $\mathrm{S}$ & Hap. & $\mathrm{N}$ & $\mathrm{nH}$ & $\mathrm{Hd}$ & $\pi\left(.10^{-3}\right)$ & $\mathrm{S}$ & Hap. \\
\hline \multirow{8}{*}{$\begin{array}{l}\text { Magdalena river } \\
\text { valley }\end{array}$} & ARM & 15 & 1 & 0 & 0 & 0 & H1(15) & 14 & 1 & 0 & 0 & 0 & H1(14) \\
\hline & MAR & 14 & 2 & 0.14 & 0.98 & 5 & H1(13), & 14 & 2 & 0.14 & 0.37 & 2 & $\mathrm{H} 1(13)$, \\
\hline & & & & & & & $\mathrm{H} 2(1)$ & & & & & & $\mathrm{H} 2(1)$ \\
\hline & IBG & 16 & 1 & 0 & 0 & 0 & H1(16) & 14 & 1 & 0 & 0 & 0 & H1(14) \\
\hline & VEN & 12 & 1 & 0 & 0 & 0 & H1(12) & 14 & 4 & 0.40 & 1.00 & 3 & $\mathrm{H} 1(11)$, \\
\hline & & & & & & & & & & & & & $\mathrm{H} 2(1), \mathrm{H} 3(1)$, \\
\hline & & & & & & & & & & & & & $\mathrm{H} 4(1)$ \\
\hline & CHA & 4 & 1 & 0 & 0 & 0 & $\mathrm{H} 1(4)$ & 5 & 1 & 0 & 0 & 0 & $\mathrm{H} 1(5)$ \\
\hline \multirow[t]{3}{*}{ Cauca river valley } & MED & 5 & 2 & 0.40 & 2.74 & 5 & H1(1), H2(4) & 5 & 2 & 0.40 & 1.04 & 2 & H1(1), H2(4) \\
\hline & CLI & 7 & 1 & 0 & 0 & 0 & $\mathrm{H} 1(7)$ & 8 & 1 & 0 & 0 & 0 & $\mathrm{H} 1(8)$ \\
\hline & QUI & 3 & 1 & 0 & 0 & 0 & H1(3) & 5 & 1 & 0 & 0 & 0 & $\mathrm{H} 1(5)$ \\
\hline \multirow[t]{2}{*}{ Caribbean coast } & $\mathrm{COR}$ & 1 & 1 & - & - & - & $\mathrm{H} 2(1)$ & 0 & - & - & - & - & - \\
\hline & BOL & 3 & 3 & 1.00 & 4.57 & 5 & $\mathrm{H} 1(1), \mathrm{H} 2(1)$ & 3 & 2 & 0.67 & 2.60 & 3 & H1(2), H4(1) \\
\hline
\end{tabular}


Table 3. Analysis of molecular variance (AMOVA) for Anacardium excelsum distributed across four Colombian regions for: A) seven nuclear inter-simple

Magdalena river valley, Cauca river valley, Caribbean coast, and Chicamocha canyon.

\begin{tabular}{lcccc}
\hline Source of variation & d.f. & Sum of squares & Variance components & $\%$ total variance \\
\hline ISSR & & & & \\
Among regions & 3 & 62.417 & 0.633 & $6 \%$ \\
Within regions & 90 & 959.370 & 10.660 & $94 \%$ \\
$\Phi_{\mathrm{ST}}$ & $0.056(p=0.012)$ & & \\
\hline
\end{tabular}

$\operatorname{trn\mathrm {L}-\operatorname {trnF}}$

\begin{tabular}{|c|c|c|c|c|}
\hline Among regions & 3 & 36.415 & 0.868 & $75 \%$ \\
\hline Within regions & 83 & 23.585 & 0.284 & $25 \%$ \\
\hline$\Phi_{\mathrm{ST}}$ & \multicolumn{4}{|c|}{$0.753(p<0.0001)$} \\
\hline \multicolumn{5}{|l|}{ rpl20-rps 12} \\
\hline Among regions & 3 & 11.460 & 0.254 & $57 \%$ \\
\hline Within regions & 85 & 16.046 & 0.189 & $43 \%$ \\
\hline$\Phi_{\mathrm{ST}}$ & 0.57 & $<0.0001)$ & & \\
\hline
\end{tabular}


Figure 1. Principal co-ordinates analysis (PCoA) of Anacardium excelsum populations based on seven nuclear inter-simple sequence repeat (ISSR) primers. Shades of grey correspond to the four sampled regions (Magdalena river valley: white, Cauca river valley: black, Caribbean coast: dark grey and Chicamocha canyon: light grey; see Table 1 for more information on the localities and the abbreviation codes).

Figure 2. Genetic differentiation among populations of Anacardium excelsum. A map including all the sampled localities is given on the left panel (A) and shades of grey correspond to the four sampled regions (Magdalena river valley: white, Cauca river valley: black, Caribbean coast: dark grey and Chicamocha canyon: light grey). The codes of each locality correspond to those noted in Table 1. B) Median-joining networks for the trnL-trnF and rpl20-rps 12 chloroplastic loci. In the networks, the size of each circle represents the occurrence rate of each haplotype and the shades of grey the corresponding sampling regions. Substitutions are indicated by a short line and the gap by a black square. C) Dendrogram computed according to the genetic similarity (Nei, 1978) through the SAHN (Sequential Agglomerative, Hierarchical and Nested Clustering) method using the NTSYS software. Data from seven nuclear inter-simple sequence repeat (ISSR) primers was used for tree reconstruction.

Figure 3. Bayesian assignment of individuals of Anacardium excelsum into genetic clusters using the program STRUCTURE based on seven nuclear inter-simple sequence repeat (ISSR) primers. A) Values obtained for the mean posterior probability of the data $(\operatorname{Ln} \operatorname{Pr}(\mathrm{X} \mid \mathrm{K}))$ and plotted against various values of K tested, suggesting $\mathrm{K}=3$ as the most likely number of clusters. B) Bayesian assignment of individuals into $\mathrm{K}=3$ genetic clusters. Each individual is represented by a vertical line, and each color represents a single cluster. The height of each color denotes the probability of an individual being assigned to the respective cluster. Individuals are arranged into populations from which they were sampled. C) Distribution of individuals with distinct level of admixture between genetic groups across sampled localities of $A$. excelsum. The pie charts' color-code is: red = individuals assigned to the red genetic group with cluster membership of 0.60 or 
higher, yellow = individuals assigned to the yellow genetic group with cluster membership of 0.60 or higher, blue $=$ individuals assigned to the blue genetic group with cluster membership of 0.60 or higher and white with black stripes $=$ admixed individuals. Circles sizes are proportional to number of individuals. The code of each locality corresponds to those noted in Table 1. occidentale (KY635877) was used as an outgroup. Bootstrap values (1,000 replicates) are given when superior to 75 . For each unique concatenated sequence, localities where encountered - directly followed by the number of sampled individuals presenting this sequence between parentheses - are given. Correspondence with haplotypes presented in Table 2 for the $\operatorname{trn} \mathrm{L}-\operatorname{trn} \mathrm{F}$ and $\operatorname{rpl20}$-rps 12 is given on the right for each unique concatenated sequence. Abbreviations of locality names are noted in Table 1. 
Table S1. ISSR's primers used in Colombian A. excelsum populations, with their respective sequences, annealing temperatures and number of bands.

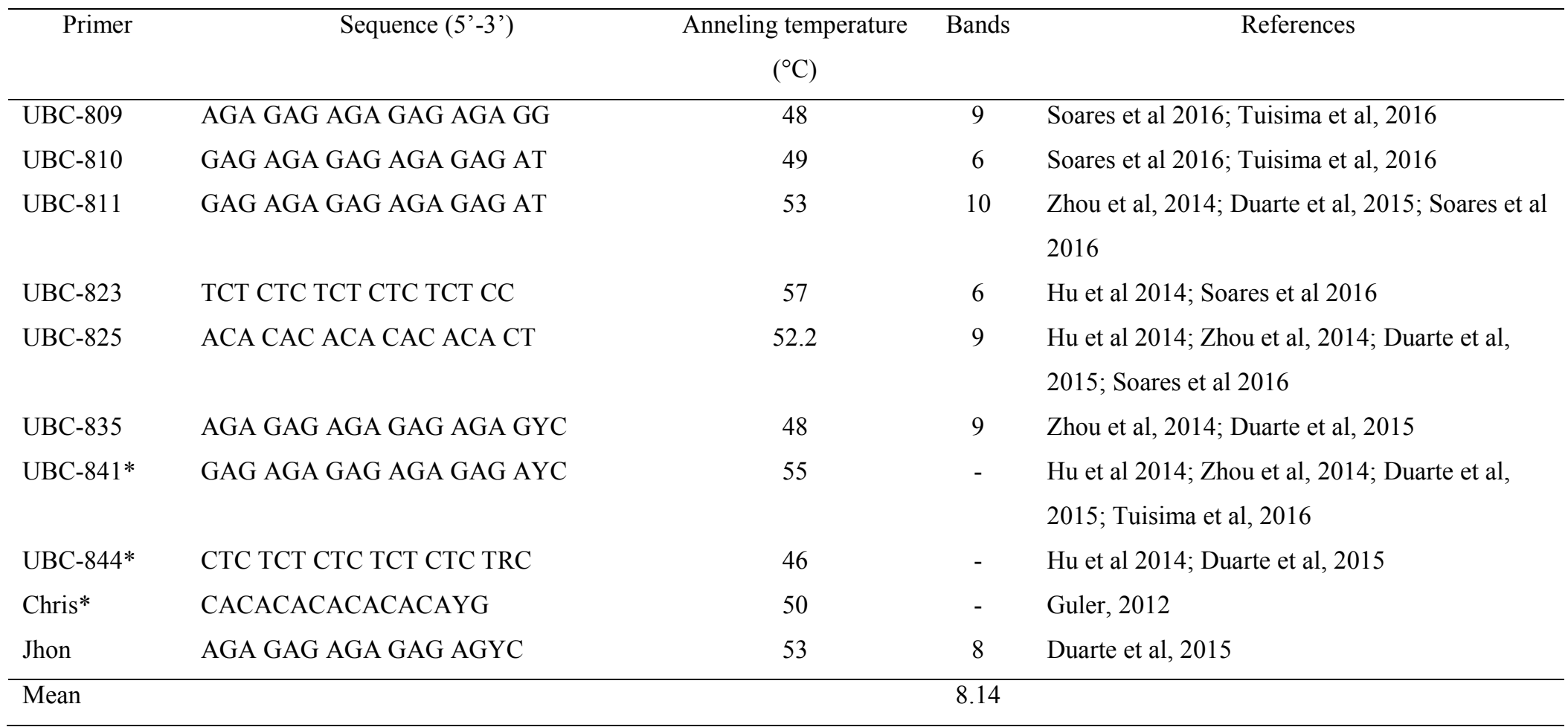

* Not kept for genetic analyses due to high numbers of missing data, see Results section for details.

Duarte JF, de Carvalho D, de Almeida VF (2015) Genetic conservation of Ficus bonijesulapensis RM Castro in a dry forest on limestone outcrops. Biochem Sys Ecol 59:54-62

Guler Y (2012) Population dynamics and sexdetermining mechanisms in the marine amphipod, Echinogammarus marinus. PhD Dissertation, University of Portsmouth 
Hu ZY, Lin L, Deng JF et al (2014) Genetic diversity and differentiation among populations of Bretschneidera sinensis (Bretschneideraceae), a narrowly distributed and endemic species in China, detected by inter-simple sequence repeat (ISSR). Biochem Sys Ecol 56:104-110

Soares ANR, Vitória MF, Nascimento ALS et al (2016) Genetic diversity in natural populations of mangaba in Sergipe, the largest producer State in Brazil. Genet Mol Res 15:1503-8624

Tuisima-Coral LL, Hlásná-Čepková P, Lojka B et al (2016) Genetic diversity in Guazuma crinita from eleven provenances in the Peruvian Amazon revealed by ISSR markers. Bosque 37:63-70

Zhou TH, Wu KX, Qian ZQ et al (2014) Genetic diversity of the threatened Chinese endemic plant, Sinowilsonia henryi Hemsi.(Hamamelidaceae), revealed by inter-simple sequence repeat (ISSR) markers. Biochem Sys Ecol 56:171-177 
Table S2: Matrices based on pairwise $\Phi_{\mathrm{ST}}$ distance between sampling regions of Anacardium excelsum using molecular markers (values below the diagonal and significance, $\mathrm{p}<0.05$, in bold). Levels of significance are based on 10,000 permutations (values above diagonal). Results are given for seven nuclear inter-simple sequence repeat (ISSR) primers, and two chloroplastic loci: trnL-trnF and rpl20-rps12. Regions were defined as in Table 1. Note that the locality of BOL, corresponding to a botanical garden, was not included in the analysis.

\begin{tabular}{|c|c|c|c|c|}
\hline \multicolumn{5}{|l|}{ ISSR } \\
\hline Region & Magdalena river valley & Cauca river valley & Caribbean coast & Chicamocha canyon \\
\hline Magdalena river valley & _- & 0.006 & 0.005 & 0.001 \\
\hline Cauca river valley & 0.025 & - & 0.374 & 0.003 \\
\hline Caribbean coast & 0.072 & 0.005 & - & 0.002 \\
\hline Chicamocha canyon & 0.121 & 0.101 & 0.263 & - \\
\hline \multicolumn{5}{|l|}{$\operatorname{trn} \mathbf{L}-t r n \mathbf{F}$} \\
\hline Region & Magdalena river valley & Cauca river valley & Caribbean coast & Chicamocha canyon \\
\hline Magdalena river valley & - & 0.005 & 0.000 & 0.000 \\
\hline Cauca river valley & 0.355 & _- & 0.111 & 0.003 \\
\hline Caribbean coast & 0.898 & 0.295 & - & 0.016 \\
\hline Chicamocha canyon & 0.969 & 0.619 & 0.417 & - \\
\hline \multicolumn{5}{|l|}{ rpl20-rps12 } \\
\hline Region & Magdalena river valley & Cauca river valley & Caribbean coast & Chicamocha canyon \\
\hline Magdalena river valley & - & 0.043 & 0.005 & 0.000 \\
\hline Cauca river valley & 0.105 & - & 0.069 & 0.002 \\
\hline Caribbean coast & 0.626 & 0.200 & - & 0.004 \\
\hline Chicamocha canyon & 0.882 & 0.669 & 0.503 & - \\
\hline
\end{tabular}


1

2

3

5653

7

8

9

10

11

12

13

14

15

16

17

18

19

20

21

22

23

24

25

26

27

28

29

30

31

32

33

34

35

36

37

38

39

40

41

42

43

44

45

46

47

48

49

50

51

52

53

54

55

56

57

58

59

60

61

62

63

64 


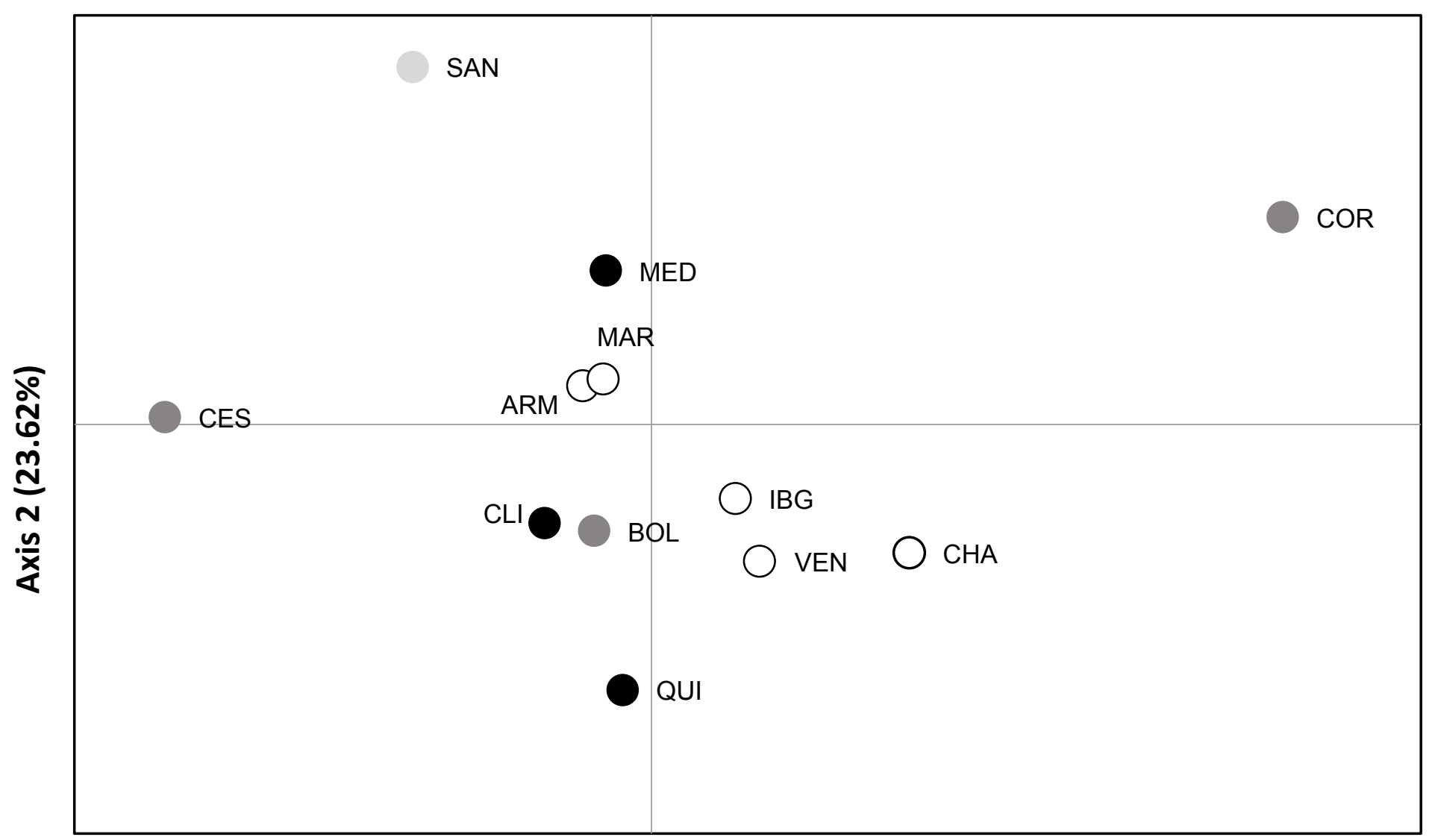

Axis 1 (42.97\%)

Magdalena river valley

Cauca river valley

Caribbean coast

Chicamocha canyon 
Click here to download Figure new Figure 2.pdf $\underline{\underline{ }}$

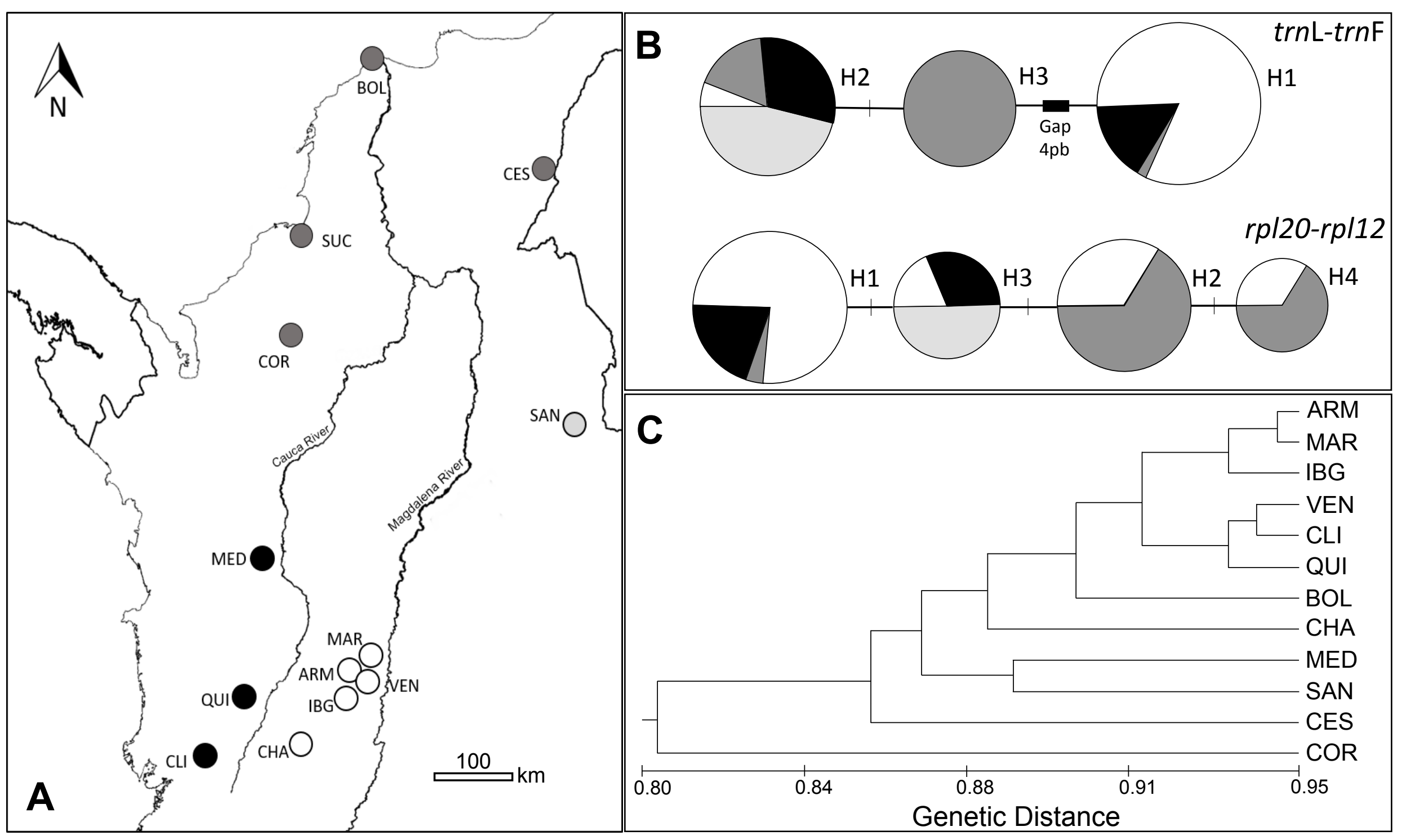




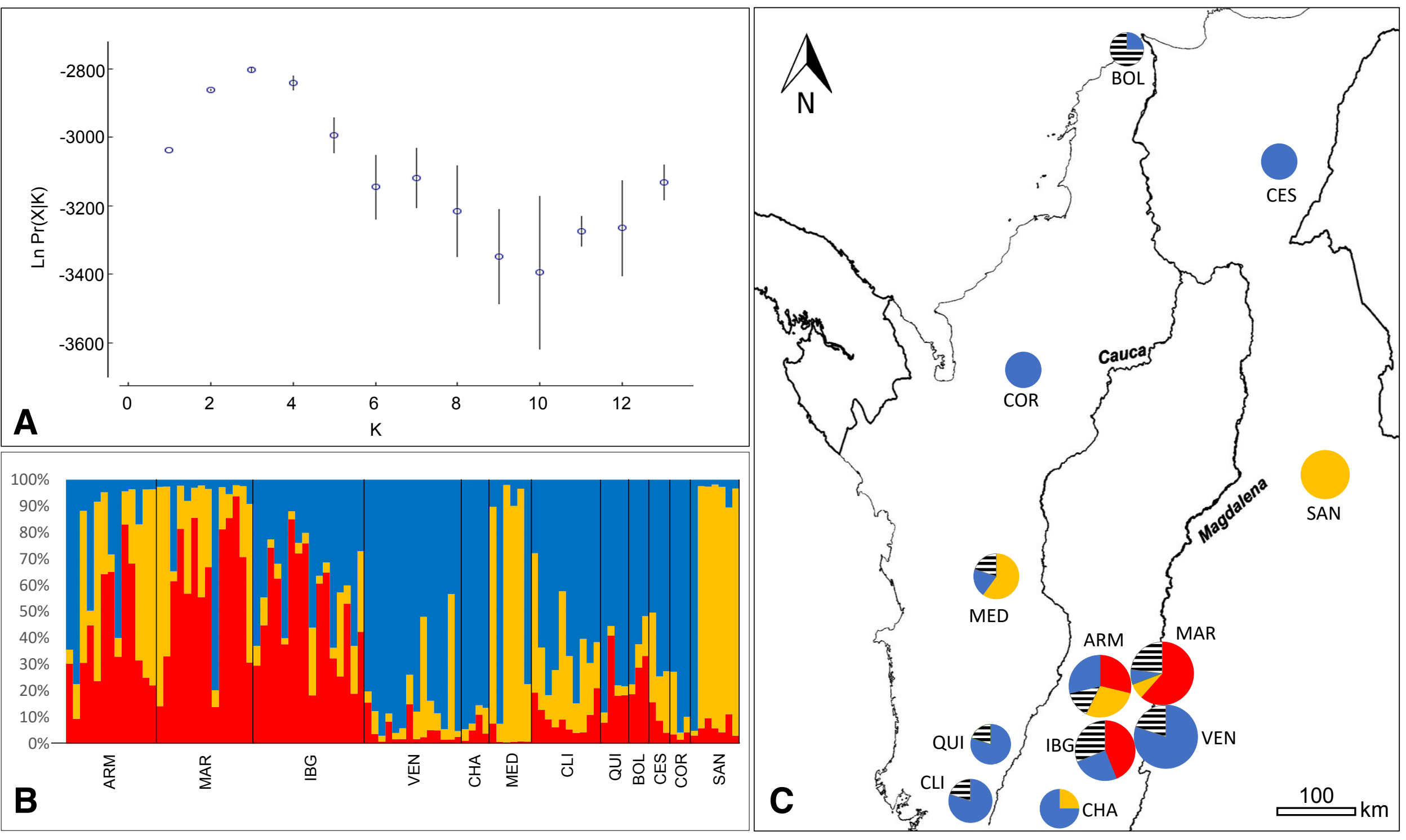


Click here to download Figure new Figure 4.pdf $\underline{\underline{ }}$

\section{trnL-trnF $\quad r p / 20-r p / 12$}

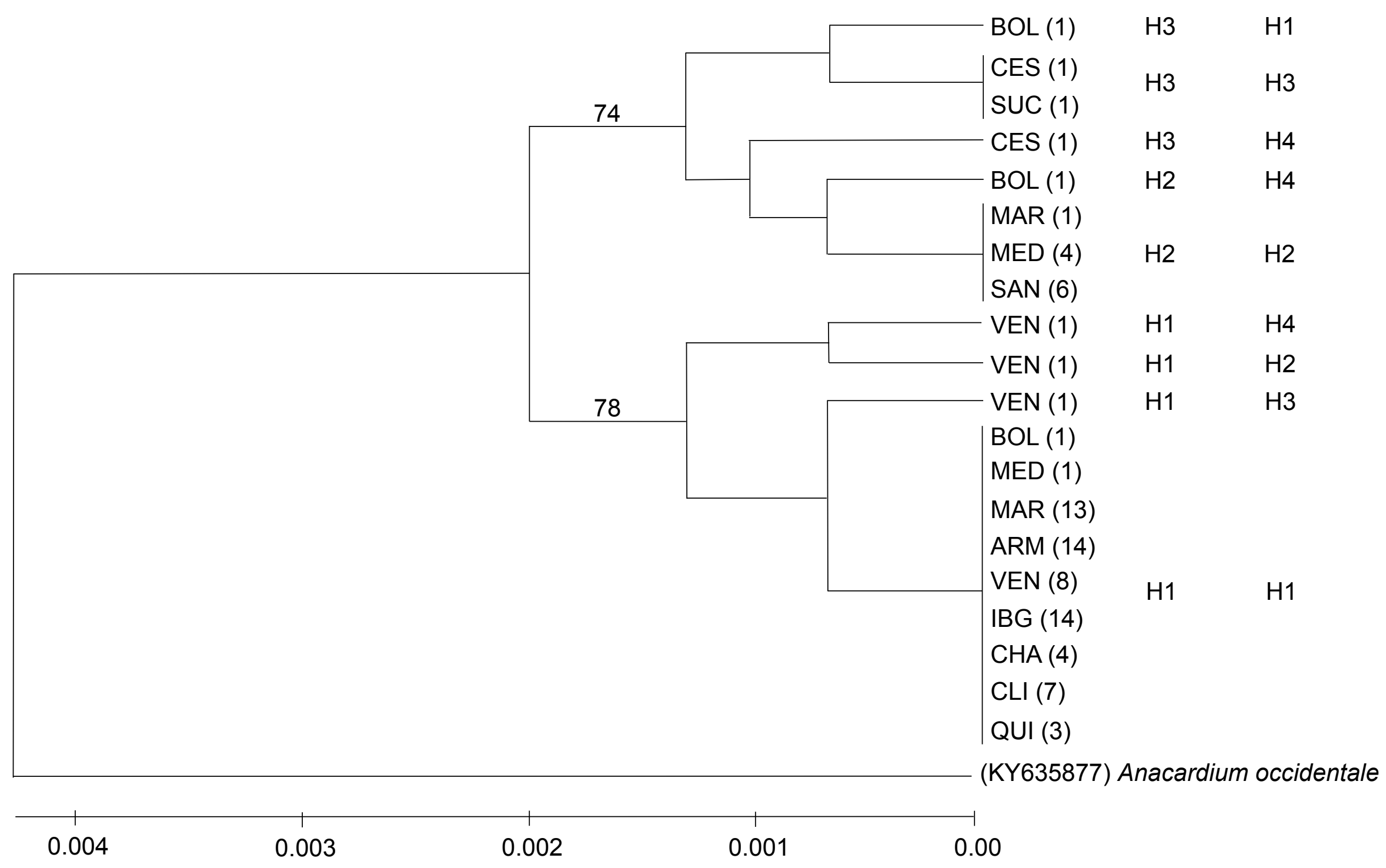

